\title{
Louise Kennefick*
}

\section{Introduction}

The landscape of criminal justice is in flux; however, little has been said as to how recent developments correlate with current discourse in criminal law theory. The rise of such movements as restorative justice, holistic justice and therapeutic jurisprudence has resulted in a shift within the criminal justice sphere. ${ }^{1}$ Traditional, punitive approaches have given way to more practical schemes, such as diversion schemes and problem-solving courts, which seek to engender empathy for those individuals who find themselves embroiled in the criminal justice system, and pay heed to the emotionality and vulnerability inherent in such situations. This essay will focus on therapeutic jurisprudence, in particular, as one methodology which provides a lens through which a more holistic approach to law may be taken. It argues that the concept can provide a normative link between emerging, more contextualised theories of criminal law, and the practices and techniques employed within the criminal justice system. In doing so, it examines current trends in criminal law theory which put the 'real world' individual to the fore, and which seek to address the disconnect inherent in the traditional, Kantian supposition. It does not argue for a general, overarching theory which spans the realms of criminal law and criminal justice, but recognises that for criminal law theory to remain relevant it must reflect, to some degree, the practices and techniques currently at play in the criminal justice system.

The forbearers of therapeutic jurisprudence describe it as the 'study of the role of the law as a therapeutic agent' (Wexler and Winick, 1996: xvii). The concept emerged in the late 1980s as a theory of mental health law.2 (Wexler, 1990, 2013; Wexler and Winick, , 1991a, 1991b, 1996). The scope of therapeutic jurisprudence has since expanded to apply to most areas of law, and has shown particular promise within criminal justice process and procedure. Within that remit, its

\footnotetext{
${ }^{*}$ Lecturer in Law, National University of Ireland Maynooth.

${ }^{1}$ Such movements have been referred to by Susan Daicoff as 'vectors' of what she has coined the 'Comprehensive Law Movement'. Other vectors include preventative law, procedural justice, integrated law, facilitative mediation, transformative mediation, collaborative law and creative problem-solving. (Daicoff, 2000: 465-92). For discussion of the similarity between restorative justice and therapeutic jurisprudence, see Braithwaite (2002).

${ }^{2}$ For a detailed account of the emergence of therapeutic jurisprudence, see Wexler, 2013a.
} 
intention is not to replace traditional approaches to criminal justice, but to bring to light the fact that it is somewhat '...anachronistic to use a system oriented around themes of retribution, punishment, deterrence, and protection to address individuals more mentally afflicted than criminally motivated ... .' (Schneider, Bloom and Heerema, 2007:43). (The latter sentiment could equally apply to those with drug and alcohol issues and other social difficulties). Thus, the aim of a therapeutic approach to criminal justice is not to usurp conventional principles of punishment, but to operate within such a framework in order to have a more appropriate impact on the offender (Schneider, et al., 2007: 43-46).

The traditional principles of punishment (particularly retribution) to which therapeutic jurisprudence provides an alternative, emerge from a view of the individual as a rational, selfcontained entity. This approach is born from a Kantian, capacity based philosophy which continues to dominate criminal law theory. Thus, the prevailing view of the individual within the criminal law is grounded upon his ${ }^{3}$ ability to reason, without consideration of his social and moral context. Clearly, such an approach is at odds with the spirit of therapeutic jurisprudence in terms of practice and technique. But is there an alternative conception - one which shares the values of therapeutic jurisprudence - that can challenge the capacity based view of the individual on a theoretical level? In recent years, a wave of scholarship has emerged which possesses the potential to do just that.

Dynamic theses, such as Antony Duff's liberal communitarianism, Alan Norrie's dialectic blaming relation, and Nicola Lacey's socio-historical thesis, have breached the boundaries of the traditional, Kantian approach to blame and punishment. They seem to recognise, where more traditional theory does not, ${ }^{4}$ the fact that the individual is innately vulnerable to the environment from which he emerges. Though acknowledging that the scholarship in question may differ in substance, this essay employs the term 'contextualised approach' as a means of capturing the essence which is common to all. The core issue with such theories, however, is that by their nature, they do not tend to lend themselves to practical application. What is needed, therefore, is

\footnotetext{
3 This paper employs the use of the masculine pronoun when describing individuals and should be read so that the masculine connotes the feminine unless otherwise indicated.

${ }^{4}$ For example, see Michael Moore's Placing Blame (1997) wherein Moore builds upon Kant's philosophy with his defence of a functional nature to criminal law, the object of that function being retribution.
} 
an appropriate mechanism whereby the spirit of such ideologies can have a tangible effect 'on the ground'.

The first part of this essay provides an overview of the traditional approach to criminal law theory, before seeking to capture the fundamental nature of the contextualised movement. In particular, it focuses on the scholarship of Norrie and Duff in order to show how such theories address the moral and social disconnect within the traditional, Kantian supposition. The second part examines how the capacity based approach is reflected in the criminal justice system. The concept of therapeutic jurisprudence is assessed with a view to establishing whether it can act as a framework within the criminal justice realm, whereby the contextualised approach to criminal law theory may be reflected in practice.

\section{Criminal Law Theory: The Kantian Supposition}

Notwithstanding the expansion of strict liability offences, the capacity based approach to responsibility has held its position within the field of criminal law theory. This is evidenced by a profusion of scholarship concerning what are regarded as the 'core' crimes for example, murder, rape and theft - all of which involve a strong mens rea element. Indeed, Nicola Lacey contends that this remains the 'dominant way of thinking about responsibility in contemporary British and American criminal law doctrine' (Lacey, 2007:236). Furthermore, Norrie (2007:252) alludes to the supremacy of the capacity based approach in his analysis of an historical account of criminal liability:

'.. underlying all the twists and turns of history, there is this basic sense of a new liberal mode of legitimation based upon a 'thin' conception of responsibility, on the possibility of identifying 'factual' psychological mental states in all persons regardless of social class and status.'

Essentially, the capacity based approach assumes that an individual exercises a choice when he commits a crime. To have the ability to make a choice, an individual must be responsible for his own actions, that is, he must have capacity and independence. Thus, the law may respond to his rational status by applying a logical mechanism to a set of behavioural characteristics and circumstances, in order to validate the attribution of blame and the imposition of punishment. 
Conversely, if an individual is considered not to have the capacity to make a choice, for example, by reason of a mental disorder, he is deemed not responsible and therefore not guilty of a crime.

The capacity based approach derives from Immanuel Kant's $(1965,1998)$ seminal theory of the abstract, universal individual, existing as a separate entity from his moral context. Such an individual morally relates to the rest of humanity on the basis of his capacity for reason, thus justifying the use of blame and punishment should this social contract be breached. According to Kant's philosophy, then, '[w]hen ... I enact a penal law against myself as a criminal it is the pure juridical legislative reason ... in me that submits myself to the penal law as a person capable of committing a crime... .' (1965:100). The remainder of this section will analyse a core criticism pertaining to the capacity based approach, before outlining more recent arguments of theorists who envisage a criminal legal system which takes a more contextualised approach to blame.

A deep-rooted theme of criminal law theory, even in the case of differing surface philosophies, is that the criminal law is built upon a moral core, whereby criminal responsibility is constructed so as to align moral responsibility with legal responsibility. However, this assumption is easily contested if the framework is expanded to include the legal individual's moral context, as is demonstrated by Kant's own examples of the soldier and the mother. ${ }^{5}$ Thus, while it may be accepted that the capacity based approach ensures a degree of equality for all those who come before the law, it also results in the 'real' moral and social context of the individual being ignored. The universal application of a set of rules based on rationality may bring a degree of certainty and order, however, it also brings with it social exclusion and moral anomaly.

Dissatisfaction with the curtailment of the accused's moral and social context within the criminal law is evidenced in practice. The courts, for one, respond to the strict constraints of the capacity based approach by tempering judgments with 'policy arguments' on a regular basis. Norrie (2005: 125-126) argues that such a practice is due to the fact that judges are not entirely convinced by the traditional, capacity based approach to criminal responsibility. On the one hand, it has been argued that such occurrences are merely paying homage to the imperfect society we live in and

\footnotetext{
${ }^{5}$ Kant was troubled by the fact that a mother who kills her child born outside marriage, or a soldier who kills in a duel, both commit a criminal act, but out of a sense of what their society perceives as 'honour'. It is their respective social contexts and their own moral perceptions which have prompted their actions, not their 'juridicial legislative reasoning' $(1965: 107)$.
} 
the concessions we must make as a result of that; on the other hand, it has been argued that it is simply not right, in a moral sense, to apply the traditional, capacity based approach in certain cases.

Another example of the expansion of the moral context in practice is the supplementation of moral information in legal categories; for example, the partial defence of provocation in Ireland employs a subjective test when taking into account the mental state of the defendant. ${ }^{6}$ Norrie (2002:554) describes the above practice as a 'particularising supplement' to universal mental states such as intention and recklessness. For him, this practice acts to undermine grand theories of criminal law such as those advanced by Kant and Hegel, ${ }^{7}$ by supplementing them with a debate as to what constitutes good and what constitutes evil: '[i]n the debate around orthodox subjectivism, the particular is there as the moral contextualisation that says that this intention or recklessness is good, this is bad.' (Norrie, 2002:555).

It is discussed below how the underlying philosophy of the Kantian approach is reflected in the criminal justice realm by the 'just deserts' theory. The rise of such movements as therapeutic jurisprudence, then, is testament to the fact that though the Kantian approach may be plausible in theory, it does not fulfil the moral needs of society in practice. So while the traditional, Kantian approach may be under threat 'on the ground', let us consider the response of criminal law theory.

\section{Criminal Law Theory: The Contextualised Approach}

In terms of a theoretical reaction to the dominance of the capacity based approach, there has been a marked movement towards a more contextualised means of attributing blame. Scholars such as Norrie (1991, 1993, 1998, 2001, 2004, 2005, 2009, 2010), Lacey, (1988, 1998a, 2000, 2001ab, 2007ab, 2010), Duff $(1990,1991,1993,1998,1996,2002,2007)$ have proposed alternative frameworks which, though varied in approach, all support an expanded view of the individual

\footnotetext{
${ }^{6}$ The partial defence of provocation takes into account the character, temperament and circumstances of the accused. See D.P.P. v. MacEoin [1978] I.R. 27; D.P.P. v. Kelly [2000] 2 I.R. 1.

${ }^{7}$ Like Kant, Hegel was concerned with the notion of a unifying theory underlying experiential contents, however, his approach was more systematic in terms of making logic and therefore consciousness the ultimate source of reality (Houlgate, 1998; Miller, 1998).
} 
within the criminal law. To capture the nature of this movement, this essay will focus on the hypotheses put forward by Norrie and Duff, in particular, as two seminal theorists in this field.

In Punishment, Responsibility and Justice, Norrie (2000) argues that if the idea of fixed individual identity as promulgated by the rational legal code does not capture the nature of human being, an alternative code is required, one which is dialectic in character. The dialectic approach provides a challenge to the mode of thinking inherent in the notion of the fixed character of the Kantian individual by offering a critique of 'false separation', the basis of which is a means of understanding how socially connected, relational, individuals subscribe to an alternative model of legal and moral analysis $(2000: 12)$. Norrie $(1991,1993)$ builds upon an analysis that applies new methodological, historical, psychological, and ethical approaches to the liberal Kantian framework; the product of this is the idea of blame as a relational concept.

It is clear, however, that Norrie (2000:13) does not wish to dismiss the notion of individual justice, but rather to recast it in a fundamental way. Therefore, his hypothesis aims not to make light of the notion of the individual, but rather to emphasise the dialectical concept that responsibility exists both in and beyond the individual moral agent in the same moment. Responsibility does not exist solely within the cognitive characteristics of individual, but is shared between that individual and the 'significant others' within his community (2000:14). So for Norrie (2000:14), while the Kantian mode of understanding responsibility (i.e. 'reflecting and rationalising legal modes') is falsely separative and non-relational, the Kantian question about the nature of responsibility still requires an answer. Thus, he argues that the Kantian focus on the individual within the criminal law is valid, even if its mode of understanding that individual is too narrow. The dialectic model redresses this restriction by retaining responsibility as an attribute of human agency, but in a relational way.

Though Norrie is somewhat critical of the Aristotilean approach as promulgated by such scholars as Ashworth and Duff, it too asserts a view of the individual not alone as an autonomous entity, but as a member of a community of norms and values. Duff, in particular, offers an apparent alternative to the Kantian individualist model which seeks to clarify existing mens rea concepts against a backdrop of advocating the legal recognition of certain morally significant distinctions. 
Duff's hypothesis of criminal law is normative in nature, in that it relies upon a theory of the politic, or, as he puts it, 'an underlying normative conception of the state and its proper relationship to its inhabitants' (2007:11). Consequently, his theory is very much dependent upon a liberal-communitarian view of the criminal law which advances the notion of 'a polity of citizens whose common life is structured by such core liberal values as autonomy, freedom, privacy and pluralism, informed by a conception of each other as fellow citizens in the shared civic enterprise' (2007:11). So, like Norrie, Duff's individual within the criminal law is concurrently a member of a moral community. A further aspect of Duff's theory is based on the ideal of punishment as a means of communication. For Duff $(1996,1998)$, the purpose of the criminal process is to facilitate a conversation between the offender, the victim, and the wider community about the offender's alleged wrongdoing. It is for the offender to explain his actions to the community, with a view to encouraging repentance; if his form of explanation fails, he will be punished for his crime (Haque, 2008).

Thus, despite their substantive differences, both Norrie's dialectic blaming relation and Duff's liberal communitarianism beget a common thread of interrelatedness, a recognition of the fact that the individual is inherently connected to his social and moral context. They stretch the Kantian paradigm by taking a more human and realistic approach to the individual within the criminal law, as opposed to the separate, rational entity that permeates formal criminal law constructs. That said, while Norrie's relational theory of blame certainly reflects the reality of the position of the individual within his community, his pervading problem is that he fails to give a concrete practical example of how a relational, dialectical theory would work in a court room or within a body of legislation. Moreover, while Duff's overall aim is indeed worthwhile, it is questionable whether he succeeds in blueprinting a system whereby the community and the individual seek to produce moral good from punishment. The core difficulty for Duff's hypothesis lies in the practicality of rationalising the institution of punishment within a communitarian context. $^{8}$

Thus, one of the innate difficulties with such theories is that they are confined to discourse. This is understandable when we consider that, for the most part, the further we move from the safety

\footnotetext{
${ }^{8}$ For a critique to this effect, see Norrie (2000:139) who argues that Duff struggles to retain successfully the notion of the autonomous individual, and ultimately fails to do so at the hands of his own, all consuming communitarian theory.
} 
of a metaphysical theory of the criminal law towards its more tangible practices, the more problematic such theories become. But does this mean that criminal law theory is redundant? Not necessarily. Criminal law theory not alone provides the language by which our discussion of the criminal law takes place (Duff, 2005:364), but it guides, analyses and challenges the law, so that its purpose and motives may be understood to the degree to which any system of such magnitude is understandable. The point is that it cannot exist validly and usefully unless it engages with the techniques, practices and procedures that affect the individual within the criminal law (Naffine, 2009:232). For, if we are to isolate theory from practice, the chances are that something important will be lost in translation.

The next section examines how the traditional, Kantian theory to the criminal law is reflected in the criminal justice system, with a view to establishing whether the contextualised approach to criminal law theory may be realised in practice via a framework of therapeutic jurisprudence.

\section{Therapeutic Jurisprudence: The Missing Link?}

It is accepted that there is no one, overarching aim of punishment. For, as Ashworth (2005:67) warns, trying to construct such an aim would be vacuous, 'since it gives no hint of the conflicts that arise and the priorities that need to be determined.' In fact, the aim of punishment is made up of rationales of sentencing, namely, prevention, deterrence, rehabilitation (utilitarian ideologies), incapacitation, and desert. The latter is based on a retributive theory of punishment, which arguably remains the dominant theory of punishment among both academics and policymakers in most common law jurisdictions (Moore, 1997; Law Reform Commission, 1996).

It is the retributive theory of desert which connects the Kantian, capacity based approach to criminal law theory to the criminal justice system, by basing distributive principles on the moral status of offenders themselves, rather than on the community of potential victims (Hudson, 2003:27). Its fundamental difference to utilitarianism, then, is that it looks to the past at the crimes previously committed by the offender, rather than to the future, and justifying 
punishment on the basis of social advantage. ${ }^{9}$ According to the retributivist ideal, individuals possess free will and are capable of making rational decisions, thus punishment is an end in itself, rather than a means, for example, to protect society (Hudson, 2003:28). The foundation of the retributive ideal is that the offender is being given his 'just deserts' as a result of committing an offence, and so 'paying the price' for his actions. This is achieved through the vindication of society for the offence committed against it, the denial of the offender of his criminal gains on the basis of fairness, and the instigation of punishment proportionate to the offender and the offence (de Londras, 2004).

It is arguable, then, that therapeutic jurisprudence is to the contextualised approach to criminal theory, as the retributive approach is to the Kantian, capacity based theory of the criminal law. It examines the notion of therapeutic jurisprudence and how it can connect criminal law theory to the 'real world', prior to considering an example of its manifestation in practice. In doing so, it shows how practices and techniques already in place demonstrate that therapeutic jurisprudence is a viable means of integrating the spirit of the contextualised approach.

The concept of therapeutic jurisprudence provides a mechanism for expanding the contextualised approach to criminal law theory outlined above into the realm of criminal justice, in that it too is normative in nature. It holds that the concept of therapy is important and ought, therefore, to feature within the remit of legal decision making (Winick, 1997). It is important because it seeks to tackle the adverse experience of vulnerable offenders within the criminal justice system, such as, being the subject of abuse, experiencing lack of meaningful treatment if the individual has a mental disorder, and being subject to higher rates of incarceration (Schneider et al., 2007:45). Its particularised nature, too, accords with the contextualised approach, in that it regards the accused as innately connected with his social and moral circumstance:

'... therapeutic jurisprudence prescribes attention to the unique circumstances of each accused and recommends the use of treatment plans tailored to the individual... standard interventions exist only insofar as standard accused exist, which of course they do not.' (Schneider et al., 2007:198).

\footnotetext{
${ }^{9}$ Hudson (2003:17) maintains that the real difficulty with theories of utilitarianism lies in '...the contingency of liberty, and of individual rights. Protection of these values is contingent upon the self-interest of happiness-seeking persons being enlightened.'
} 
In terms of its manifestation in practice, then, therapeutic jurisprudence forms the basis of several initiatives, such as mental health courts, diversion schemes, education of judges and legal professionals in a therapeutic approach, developing interpersonal skills of professionals when dealing with offenders with mental disorders, etc. ${ }^{10}$ As Schneider et al (2007:45) put it, therapeutic jurisprudence is 'a holistic and all-encompassing approach' not just in terms of how it permeates the stages of the criminal justice system, ${ }^{11}$ but also in the sense that it dissolves the divisions that exist in the current system as between behavioural sciences, social services and the criminal law, via the creation of 'a climate that supports inter-professional collaboration and creative problem solving.' (Madden and Wayne, 2003:340). Employing such a multidisciplinary approach thus ensures the achievement of a therapeutic experience for the offender in question, by means of the application of the knowledge, skills, and techniques of differing professions (Madden and Wayne, 2003:340). This methodology accords with Norrie's approach, in the sense that his dialectic blaming relation crosses the boundaries of criminal law theory in order to appreciate the influence of such fields as history, sociology and psychology upon the law and its subjects.

Therapeutic jurisprudence attempts to deal holistically with cases involving difficult socio-legal problems. It works within the criminal justice sphere by partnering the processing of cases with treatment providers and community groups to provide follow-up and support for victims and offenders alike (Wexler, 1999; Balson 2013). In this sense, it shares the values of the contextualised approach to criminal law theory which regards the individual as innately connected to his circumstance. Therapeutic jurisprudence, however, takes the important step of getting the 'significant others' in the community involved with the individual in the criminal law process, so that the innate connectivity of the parties is recognised, not just in theory, but through various practices and techniques. Indeed, such a method goes some way towards bringing into practice Duff's communicative ideal.

Though as a concept, therapeutic jurisprudence enhances and makes more viable a contextualised approach to blame, it is not without its critics (Slobogin, 1995; Davis, 2003). A major difficulty

\footnotetext{
${ }^{10}$ For a summary of practical approaches with a therapeutic jurisprudential leaning, see Goldberg (2005:3-6) and more recently, Ryan and Whelan (2012).

${ }^{11}$ As an example, '... from determining whether an individual should be diverted completely from the criminal justice system and placed with a mental health-care provider, to intentionally remembering some minor detail about an accused in an effort to make her feel a little more human ... .' (Schneider, 2007:45).
} 
perceived by some is the ambiguous nature of the term 'therapeutic', the problem being that therapeutic jurisprudence aims to encompass the 'whole field' of the law, thereby overextending itself (King, 2008: Part B). However, the fact that therapeutic jurisprudence does not seek to usurp the role of more traditional means of punishment in their entirety, goes to its flexibility as a framework, rather than suggesting that it has ambitions as a grand theory. Furthermore, such a criticism may be overcome by applying therapeutic jurisprudence in a particularised manner, for example, the juncture at which individuals with a mental disorder come into contact with the criminal justice system.

It is also argued that therapeutic jurisprudence is coercive and paternalistic in nature (Casey, 2004; Nolan, 2003), whereby, for example, treatment becomes a lesser evil to punishment thus eliminating any real sense of 'choice' for the accused (Casey, 2004). However, Wexler (1993:280), would dispute such a claim on the basis that the core task of therapeutic jurisprudence is to '... determine how the law can use behavioural science information to improve therapeutic functioning without impinging upon concerns about justice.' Indeed, he is supported by Schneider et al (2007:63) who describe such a criticism as 'absurd': 'It is twisted logic to suggest that we revert to traditional criminal justice sanctions, simply to avoid choice. If choice is capable of inducing coercion, perhaps it would be best to discard the traditional sanctions as options.' (2007:64). More recently, Ryan and Whelan (2012) suggest practical examples of how therapeutic jurisprudence may be applied so that paternalistic interference can be overcome in the context of mental health courts, for example, with the appointment of a solicitor to act on behalf of the defendant at the first indication that he could be eligible to participate.

Indeed, one example of a more prominent technique which encapsulates the contextualised approach is the problem-solving or 'solution-focused' court (King, 2009). Such courts are founded upon the principles of therapeutic jurisprudence and have developed in response to the realisation that a 'one size fits all' approach to criminal justice does not work in some contexts. Just like in criminal law theory, the traditional criminal justice model cannot handle effectively the complexity of certain human and social problems, and as such, initiatives have emerged that are designed to enable courts to respond more appropriately to cases in which complex social and personal issues are involved (Bahkt, 2005; Ryan and Whelan, 2012). 
The essence of this innovation is that rather than merely imposing a sentence or making some other disposition, the trial judge remains involved with the case and exercises some degree of oversight or supervision over the progress of the offender (O'Malley, 2006:408). This, in turn, requires substantial collaboration with social services agencies which must also be willing to work with the offender. The principal characteristic of such a court involves using court authority to:

'... forge new responses to chronic social, human and legal problems that have proven resistant to conventional solutions. They seek to broaden the focus of legal proceedings, from simply adjudicating past facts and legal issues to an early intervention into the behaviour of litigants.' (CPS, 2005).

Though further empirical investigation is required, it would appear from research conducted to date that problem-solving courts can achieve considerable success (Schwartz, 2008; Sarteschi et al 2011). The idea is clearly transferable to any jurisdiction, but other agencies must be willing to cooperate, and the resources and facilities must be provided to ensure that offenders are given every reasonable opportunity to address the problems leading to their offending (O'Malley, 2006:408). As just one example of the practice of therapeutic jurisprudence, it demonstrates that the ideals of the contextualised approach to criminal law theory may be brought to fruition 'on the ground'.

More recently, therapeutic jurisprudence scholars have given significant consideration to the relationship between therapeutic jurisprudence in a broader sense, ${ }^{12}$ and the adversarial system of law (Freiberg, 2001; Balson, 2013). ${ }^{13}$ Stobbs, for one, has investigated whether therapeutic jurisprudence is incommensurable with the traditional adversarial approach in the context of Thomas Kuhn's theory of scientific revolutions (Stobbs, 2013). He asserts that while the two may be incommensurable, the notion of a 'therapeutic paradigm shift in law' is conceivable if the incommensurable nature of the relationship is related to a 'broader disciplinary matrix'. Thus, the influence of therapeutic jurisprudence on mainstream criminal justice is likely to evolve in response to the needs and intuitions of practitioners when faced with seemingly intractable

\footnotetext{
12 Though note that most therapeutic jurisprudence scholars would argue that it is not yet a normative theoretical framework, for example, see Wexler's useful wine and bottles analogy, where therapeutic jurisprudence practices amount to a 'liquid' and the mainstream legal rules as 'bottles' (Wexler, 2013b).

${ }^{13}$ Note the ongoing international project to 'mainstream' therapeutic jurisprudence, 'Integrating the Healing Approach to Criminal Law', which forms part of the Innovating Justice platform of the Hague Institute for the Internationalisation of Law, see further, http://www.hiil.org/insight/integrating-the-healing-approach-to-criminal-law.
} 
problems in the current system, as opposed to arriving as a fully fledged philosophy with a preordained set of exemplars. ${ }^{14}$ Furthermore, whether the growing influence of therapeutic jurisprudence in mainstream practice will 'rub off' on the conception of the individual within the criminal law remains to be seen, but watch this space.

\section{Conclusion}

This essay has sought to give an overview of how the conception of therapeutic jurisprudence as applied to criminal justice provides the normative link between a contextualised view of the individual within criminal law theory, and the practices and techniques at play in the criminal justice system. Because therapeutic jurisprudence '... strives to be a vehicle that elicits a more nuanced societal response to proscribed behaviour' (Schneider et al., 2007:3), it has the potential to facilitate the practical manifestation of the contextualised approach, the purpose of both being to narrow the divide between the offender and his social and moral context.

\footnotetext{
${ }^{14}$ Such evolution may be seen in the changing role of the defence lawyer. For example, Dale Dewhurst argues that lawyers need to take a more comprehensive (and arguably contextualised) approach in order to properly identify their client's 'actual best interests' and to provide the most appropriate legal advice, for example, by referring to the expertise of other professionals during case planning (Dewhurst, 2013).
} 


\section{References}

Ashworth, A. (2005). Sentencing and Criminal Justice, $4^{\text {th }}$ ed. Cambridge: Cambridge University Press.

Bahkt, N. (2005). 'Problem Solving Courts as Agents of Change'. Criminal Law Quarterly, 50:1238.

Balson, J. (2013). 'Therapeutic Jurisprudence: Facilitating Healing in Crime Victims'. Phoenix Law Review, 6:1017.

Braithwaite, J. (2002). 'Restorative Justice and Therapeutic Jurisprudence'. Criminal Law Bulletin, 38 (2):244-262.

Casey, T. (2004). 'When good intentions are not enough: problem-solving courts and the impending crisis of legitimacy'. Southern Methodist University Law Review 57: 1459.

Crown Prosecution Services and Department of Constitutional Affairs, (2005). Review of the effectiveness of specialist courts in other jurisdictions. London: H.M. Stationary Office.

D.P.P. v. Kelly [2000] 2 I.R. 1.

D.P.P. v. MacEoin [1978] I.R. 27

Daicoff, S. (2000). 'The Role of Therapeutic Jurisprudence within the Comprehensive Law Movement'. In: Stolle, D. P. et al. eds. Practicing Therapeutic Jurisprudence: The Law as a Helping Profession. Durham N. C.: Carolina Academic Press.

Davis, W. (2003). 'Special Problems for Speciality Courts'. ABA Journal, 89:32.

de Londras, F. (2004). 'Kow Towing to the Twin Gods of Time and Money: The Guilty Plea Discount in Sentencing'. Irish Criminal Law Journal 14 (1):14.

Dewhurst, D. (2013). 'Understanding the Legal Client's Best Interests: Lessons from Therapeutic Jurisprudence and Comprehensive Justice'. Phoenix Law Review, 6:963.

Duff, R. A. (1990). Intention, Agency and Criminal Liability: Philosophy of Action and the Criminal Law. Oxford: Blackwell.

Duff, R. A. (1991). Trials and Punishment. Cambridge: Cambridge University Press. 
Duff, R. A. (1993). 'Choice, Character and Criminal Liability'. Journal of Law and Philosophy, 12 (4):345.

Duff, R. A. (1996). 'Penal Communications: Recent Work in the Philosophy of Punishment'. Crime and Justice, 20:1.

Duff, R. A. (1998). 'Law, Language and Community: Some Preconditions of Criminal Liability'. Oxford Journal of Legal Studies, 18 (2):189.

Duff, R. A. (2002). 'Virtue, Vice and Criminal Liability: Do We Want an Artistotelian Criminal Law?'. Buffalo Criminal Law Review, 6:147.

Duff, R. A. (2005). 'Theorizing Criminal Law: a 25th Anniversary Essay' Oxford Journal of Legal Studies, 25 (3):353.

Duff, R. A. (2007). Answering for Crime: Responsibility and Liability in the Criminal Law. Oxford: Hart Publishing.

Goldberg, S. (2005). Judging for the 21st Century: A Problem-solving Approach. Ottawa: National Judicial Institute.

Freiberg, A. 'Problem-Oriented Courts: Innovative Solutions To Intractable Problems?' (2001). Journal Of Judicial Administration 11:8.

Haque, A. (2008). 'Review of RA Duff, Answering for Crime: Responsibility and Liability in the Criminal Law'. Law and Politics Book Review 18 (5):423.

Houlgate, S. (Ed.). (1998). The Hegel Reader. Oxford: Blackwell Publishing Limited.

Hudson, B. (2003). Justice in the Risk Society. London: Sage Publications Limited.

Irish Penal Reform Trust, (2001). Community Solutions to the Criminalisation of the Mentally Ill in Ireland.

Kant, I. (1965). The Metaphysical Elements of Justice. New York: Macmillan.

Kant, I. (1998). Critique of Pure Reason. Cambridge: Cambridge University Press.

Kennedy, H.G. (2006). 'The future of forensic health services in Ireland' Irish Journal of Psychiatric Medicine, 23 (2): 45-46.

King, M. (2009). Solution-Focused Courts Bench Book, available online through the Australasian Therapeutic Jurisprudence Clearinghouse and on the bibliography of the TJ website at www.therapeuticjurisprudence.org.

King, M. (2008). 'Restorative Justice, Therapeutic Jurisprudence and the Rise of Emotionally Intelligent Justice'. Melbourne University Law Review 32: 1096. 
Lacey, N. (1988). State Punishment: Political Principles and Community Values. London: Routledge.

Lacey, N. (1998a). 'Philosophy, History and Criminal Law Theory'. Buffalo Criminal Law Review $1(2): 295$.

Lacey, N. (1998b). 'Contingency, Coherence, and Conceptualism: Reflections on the Encounter between "Critique" and "the Philosophy of the Criminal Law". In: Duff, R. A. (Ed.), Philosophy and the Criminal Law: Principle and Critique. Cambridge: Cambridge University Press.

Lacey, N. (2000). 'Partial Defences to Homicide: Questions of Power and Principle in Imperfect and Less Imperfect Worlds'. In Ashworth A. and Mitchell, B. (Eds.), Rethinking English Homicide Law. Oxford: Oxford University Press.

Lacey, N. (2001a). 'In Search of the Responsible Subject: History, Philosophy and Social Sciences in Criminal Law Theory'. Modern Law Review, 64 (3):350.

Lacey, N. (2001b). 'Responsibility and Modernity in Criminal Law'. Journal of Political Philosophy, 9 (3): 249.

Lacey, N. (2007a). 'Space, Time and Function: Intersecting Principles of Responsibility across the Terrain of Criminal Justice'. Journal of Criminal Law and Philosophy, 1 (3):233.

Lacey, N. (2007b). 'Character, Capacity and Outcome: Towards a Framework for Assessing the Shifting Pattern of Criminal Responsibility in Modern English Law'. In: Dubber, M. And Farmer, L. (Eds.), Modern Histories of Crime and Punishment. California: Stanford University Press.

Lacey, N. (2010). 'Psychologising Jekyll, Demonising Hyde: The Strange Case of Criminal Responsibility'. Journal of Criminal Law and Philosophy, 4:109.

Law Reform Commission, (1996). LRC53, Report on Sentencing. Dublin: Stationery Office.

Madden, R. G. \& Wayne, R. H. (2003). 'Social Work and the Law: A Therapeutic Jurisprudence Perspective'. Social Work, 48 (3):338.

Mental Health Commission \& An Garda Síochána, (2009). Report of Joint Working Group on Mental Health Services and the Police.

Miller, V. (1998). Hegel's Science of Logic. New York: Humanity Books.

Moore, M. (1997). Placing Blame: A General Theory of the Criminal Law. Oxford: Clarendon Press.

Naffine, N. 'Moral Uncertainties of Rape and Murder: Problems at the Core of Criminal Law Theory'. In: McSherry, B, Norrie, A. \& Bronitt, S. (Eds.), Regulating Deviance: The Redirection of Criminalisation and the Futures of Criminal Law. Oxford and Portland Oregon: Hart Publishing. 
National Crime Council, (2007). Problem Solving Justice: The Case for Community Courts in Ireland.

Nolan, J. R. (2003). 'Redefining Criminal Courts: Problem-solving and the Meaning of Justice'. American Criminal Law Review, 40 (4):1541-1565.

Norrie, A. (1991). Law, Ideology and Punishment: Retrieval and Critique of the Liberal Ideal of Criminal Justice. Massachusetts: Kluwer Academic Publishers.

Norrie, A. (1993). Crime, Reason and History: A Critical Introduction to Criminal Law. Cambridge: Cambridge University Press.

Norrie, A. (1998). “'Simulacra of Morality”? Beyond the Ideal/Actual Antinomies of Criminal Justice'. In Duff, R. A. (Ed.), Philosophy and the Criminal Law: Principles and Critique. Cambridge: Cambridge University Press.

Norrie, A. (2000). Punishment, Responsibility and Justice: A Relational Critique. Oxford: Oxford University Press.

Norrie, A. (2001). Crime, Reason and History: A Critical Introduction to Criminal Law. $2^{\text {nd }}$ ed. London: Butterworths.

Norrie, A. (2002). 'From Criminal Law to Legal Theory: The Mysterious Case of the Reasonable Glue Sniffer'. Modern Law Review, 65 (4):538.

Norrie, A. (2004). 'Bhaskar, Adorno and the Dialectics of Modern Freedom'. Journal of Critical Realism, 3 (1):23-48.

Norrie, A. (2005). Law and the Beautiful Soul. London: Glasshouse Press.

Norrie, A. (2007). 'Historical Differentiation, Moral Judgment and the Modern Criminal Law'. Journal of Criminal Law and Philosophy, 1 (3): 251.

Norrie, A. (2009). 'Citizenship, Authoritarianism and the Changing Shape of the Criminal Law'. In: McSherry, B. et al. (Eds.), Regulating Deviance: The Redirection of Criminalisation and the Futures of Criminal Law. Oxford and Portland Oregon: Hart Publishing.

Norrie, A. (2010). Dialectic and Difference: Dialectical Critical Realism and the Grounds of Justice. London: Routledge.

O’Malley, T. (1994). 'Resisting the Temptation of Elegance: Sentencing Discretion Re-affirmed'. Irish Criminal Law Journal 4 (1):1.

O’Malley, T. (2006). Sentencing Law and Practice. $2^{\text {nd }}$ ed. Dublin: Thomson Round Hall.

Ryan, S. \& Whelan, D. (2012). 'Diversion of Offenders with Mental Disorders: Mental Health Courts'. Web Journal of Current Legal Issues. http://webjcli.ncl.ac.uk/2012/issue1/ryan1.html. 
Sarteschi, C. Vaughn, M. \& Kim, K. (2011). 'Assessing the Effectiveness of Mental Health Courts: A Quantitative Review'. Journal of Criminal Justice 39:12.

Schneider, R. D., Bloom H. \& Heerema, M. (2007). Mental Health Courts: Decriminalizing the Mentally Ill. Ontario: Irwin Law.

Schwartz, E. (2008) 'Mental Health Courts'. US News and World Report. 7 February 2008, available at http://www.usnews.com/news/national/articles/2008/02/07/mental-healthcourts_print.html.

Slobogin, C. (1995). 'Therapeutic Jurisprudence: Five Dilemmas to Ponder'. Psychology, Public Policy and Law 1 (1):193-219.

Stobbs, N. (2013). 'Mainstreaming Therapeutic Jurisprudence and the Adversarial Paradigm Incommensurability and the Possibility of a Shared Disciplinary Matrix'. PhD thesis, ePublications@bond, Faculty of Law.

The People (A.G.) v. O'Driscoll [1972] Frewen 351.

Wexler, D. B. (1990). Therapeutic Jurisprudence: The Law as a Therapeutic Agent. Durham N. C.: Carolina Academic Press.

Wexler, D. B. (1993). 'Therapeutic Jurisprudence and the Criminal Courts'. William and Mary Law Review, 35: 279.

Wexler, D. B. (1999). 'Therapeutic Jurisprudence Forum: The Development of Therapeutic Jurisprudence: From Theory to Practice'. Revista Juridica UPR 68 (3):691.

Wexler, D. B. (2013a). 'The Development of Therapeutic Jurisprudence: From Theory to Practice'. Arizona Legal Studies Discussion Paper No. 13-51; Revista Juridica UPR 68 (3):691.

Wexler, D. B. (2013b). 'New Wine in New Bottles: The Need to Sketch a Therapeutic Jurisprudence "Code"' of Proposed Criminal Processes and Practices'. Arizona Legal Studies Discussion Paper No. 12-16.

Wexler, D. B. \& Winick, B. J. (1991a). 'Therapeutic Jurisprudence as a New Approach to Mental Health Law, Policy Analysis and Research'. University of Miami Law Review, 45 (5): 979.

Wexler, D. B. and Winick, B. J. (1991b). Essays in Therapeutic Jurisprudence. Durham N. C.: Carolina Academic Press.

Wexler, D. B. \& Winick, B. J. (1996). Law in Therapeutic Key: Developments in Therapeutic Jurisprudence. Durham N. C.: Carolina Academic Press.

Winick, B. J. 'The Jurisprudence of Therapeutic Jurisprudence' (1997) Psychology, Public Policy \& Law3 (1): 184-206. 
